\title{
Proto-Oncogene DBL
}

National Cancer Institute

\section{Source}

National Cancer Institute. Proto-Oncogene DBL. NCI Thesaurus. Code C45490.

Proto-oncogene DBL (925 aa, $108 \mathrm{kD}$ ) is encoded by the human MCF2 gene. This cytoplasmic protein promotes the conversion of certain Rho GT Pases from the GDPbound form to the GTP-bound form, thereby modulating their activity. 